\title{
IDENTIFIKASI KEANEKARAGAMAN DAN SEBARAN JENIS BURUNG UNTUK PENGEMBANGAN EKOWISATA BIRD WATCHING DI TAMAN NASIONAL BANTIMURUNG BULUSARAUNG
}

\author{
Diversity and Distribution Identification of Bird Species For Bird Watching Ecotourism Development in the Bantimurung \\ Bulusaraung National Park. \\ Asrianny ${ }^{1}$, Hendra Saputra ${ }^{2}$, Amran Achmad ${ }^{1}$ \\ 1 Staf Pengajar, Fakultas Kehutanan, Universitas Hasanuddin, Makassar, ${ }^{凶}$ corresponding author: amhutan@yahoo.com \\ ${ }^{2}$ Mahasiswa, Laboratorium Konservasi Sumber Daya Hutan dan Ekowisata, \\ Fakultas Kehutanan, Universitas Hasanuddin, Makassar
}

\begin{abstract}
This study aims to identify the diversity and distribution of birds species for bird watching ecotourism development in the Bantimurung Bulusaraung National Park. Field works was conducted in three months, from October to in December 2012. Data collection, was done with line transect method at Leang-Leang, Pattunuang, and Karaenta. Geographical position of transect line (traces) was recorded by using GPS then processed with GIS in order to produced bird watching maps tourist track. Result soft his study showed that, there are 47 species of birds found in the three lines of observation track, and 23 of them (48.9\%) was endemic to the island of Sulawesi. Diversity indices of birds on the observation track at Leang-Leang is 3.02 , in Pattunuang 2.78 , and in the Karaenta 2.25. Among the three lines of observation, the highest population abundance is at Leang-Leang tracking line. It's equal to 29 individuals /ha while the lowest population abundance are on the Karaenta track with 9 individuals /ha.
\end{abstract}

Key words : Bantimurung Bulusaraung National Park, Bird Watching, Ecotourism.

\section{A. PENDAHULUAN}

Taman Nasional Bantimurung Bulusaraung yang terletak di Sulawesi Selatan kaya akan keanekaragaman hayati baik flora maupun faunanya terutama spesies burung. Berdasarkan daftar jenis satwa liar yang dihimpun dari berbagai sumber serta hasil dari kegiatan identifikasi jenis yang dilakukan oleh Balai Taman Nasional Bantimurung Bulusaraung, terdapat 116 spesies burung yang terdapat dikawasan tersebut (Taman Nasional Bantimurung Bulusaraung, 2012).

Berbagai jenis burung dapat ditemukan di dalam kawasan Taman Nasional Bantimurung Bulusaraung yang sebagian besar wilayahnya adalah merupakan ekosistem karst. Achmad dan Nurkin (1997) dalam Achmad (2011) menginformasikan tentang beberapa jenis burung yang dapat ditemukan dikawasan karst Maros-Pangkep, antara lain Julang Sulawesi (Rhyticeroscassidix), Enggang Kerdil Sulawesi (Penelopides exarhatus), Burung Elang Alap Sulawesi (Accipiter griseiceps), Burung Cekakak Sungai (Halcyonchloris), Burung Walet sapi (Collocalia esculenta), Burung Sri Gunting (Dicrurus hottentottus), Pergam Hijau (Duculaaenea), Burung Tekukur Biasa (Streptopeliachinensis), Burung Punai Hijau (Trerongriceicanda), Burung Kakak Tua Hijau (Lariculus exilis), dan Ayam Hutan (Gallus gallus).
Beberapa jenis satwa yang ada di kawasan tersebut telah dikembangkan sebagai kegiatan wisata berbasis satwa seperti pengamatan kupu-kupu dan pengamatan Monyet Hitam Sulawesi (Macacamaura). Adapun keanekaragaman jenis burung yang melimpah dapat dijadikan sebagai daya tarik wisata yang potensial untuk dikembangkan di Taman Nasional Bantimurung Bulusaraung, yaitu melalui kegiatan pengamatan burung atau dalam istilah disebut Bird Watching. Kegiatan ekowisata bird watching tidak terlepas dari upaya konservasi alam. Kegiatan bird watching adalah salah satu teknik pendidikan konservasi yang dapat memberikan pengetahuan yang berwawasan lingkungan kepada semua pihak sehingga ikut berperan dalam melestarikan sumberdaya alam serta menyusun strategi pelestarian keanekaragaman hayati sehingga berlanjutnya kerusakan sumberdaya alam bias dicegah. Berdasarkan uraian diatas maka dianggap perlu untuk melakukan penelitian identifikasi sebaran dan keanekaragaman jenis burung untuk pengembangan ekowisata bird watching di Taman Nasional Bantimurung Bulusaraung.

\section{B. METODE PENELITIAN}

Penelitian ini dilaksanakan selama 3 bulan yaitu mulai bulan Oktober sampai pada bulan Desember 2012. Lokasi penelitian bertempat di Taman Nasional 
Bantimurung Bulusaraung, tepatnya di Leang-Leang, Pattunuang, dan Karaenta. Lokasi tersebut ditetapkan berdasarkan keputusan pihak pengelola Taman Nasional Bantimurung Bulusaraung karena lokasi tersebut merupakan tempat yang berpotensi dan sangat ideal untuk dijadikan sebagai lokasi wisata bird watching.

\section{Pengumpulan data}

\section{Data Burung}

Pengambilan data burung dilakukan dengan metode garis transek (linetransect). Metode garis transek adalah metode pengamatan satwa liar melalui pengambilan contoh dengan bentuk unit contoh berupa jalur pengamatan dengan lebar jalur tidak ditentukan, sehingga semata-mata hanya jalur pengamatan. Metode garis transek dilakukan dengan berjalan sepanjang garis transek dan pengamatan dilakukan pada kedua sisi transek, kemudian jarak antara lokasi burung yang terlihat dengan pengamat ditentukan panjangnya (Soegianto, 1994). Pengamatan burung dilakukan sebanyak 2 kali untuk setiap transeknya, yaitu pada pagi hari pukul 06.00-10.00 WITA dan sore hari pada pukul 14.00-17.00 WITA. Pemilihan waktu ini diambil dengan pertimbangan bahwa puncak aktivitas burung terjadi pada pagi hari ketika mencari makan dan akan kembali ke sarangnya pada sore hari. Pengamatan dilakukan berdasarkan panjang transek sehingga pengamatan dianggap selesai apabila transek sepanjang $2 \mathrm{~km}$ telah selesai dilewati. Pengulangan dilakukan sebanyak 3 kali untuk setiap jalur pengamatan. Pengamatan dimulai dengan berjalan mengikuti arah jalur atau transek secara perlahan-lahan. Dalam pengamatan, setiap kali ada perjumpaan dengan burung maka dicatat spesies burung tersebut, jumlah individu, jarak antara garis tengah transek dan posisi satwa tersebut (y), perilaku atau aktivitas burung, kondisi cuaca,dan habitat. Metode garis transek pengamatan burung dapat dilihatpada Gambar 1.

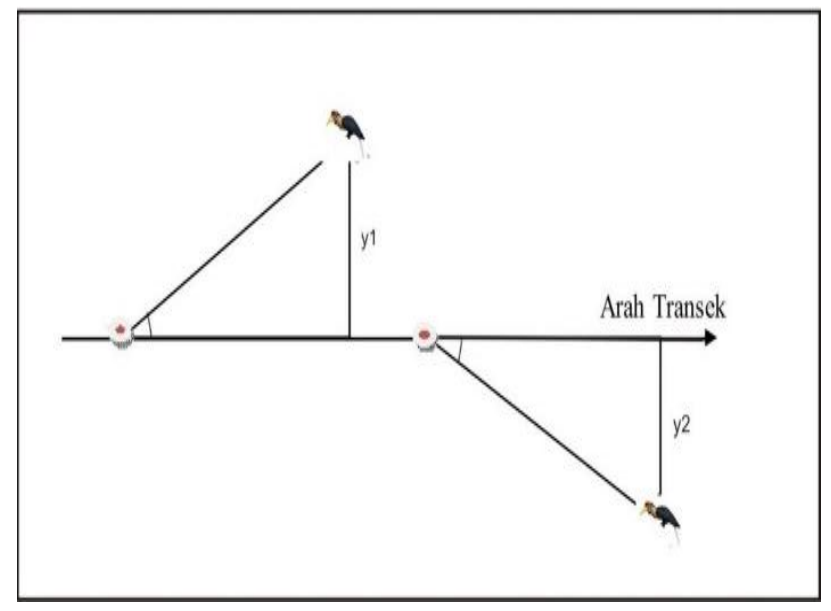

Picture 1. Transect of bird observation :- Sobserver position Position of the visible bird, $y$ : distance of middle line transect with position of object.

\section{Pemilihan Jalur Wisata Bird Watching (track)}

Jalur wisata bird watching diperoleh dari jalur yang digunakan dalam pengambilan data burung (linetransek). Metode yang digunakan yaitu merekam jejak jalur yang dilalui menggunakan GPS yang selanjutnya diolah untuk menampilkan data digital yang tersimpan di GPS dalam bentuk peta jalur bird watching. Lokasi yang dipilih untuk dijadikan sebagai jalur wisata bird watching yaitu lokasi yang memiliki keanekaragaman jenis burung yang tinggi, adanya jenis burung yang memiliki potensi untuk dikembangkan, ekosistem yang menjadi habitat burung dengan kelimpahan dan keanekaragaman jenis tinggi, tingkat pertemuan dengan burung, dan kenyamanan jalur.

\section{Analisis Data}

Analisis kualitatif dilakukan untuk mendeskripsikan aktivitas burung, habitat dan prilaku burung yang dijumpai. Sedangkan analisis kuantitatif dilakukan untuk memperoleh data kerapatan, indeks keanekaragaman jenis, indeks kekayaan, indeks kemerataan, dan kemelimpahan relatif jenis burung. Rumus-rumus yang digunakan dalam pengolahan data, antara lain:

\section{Analisis Data}

Analisis kualitatif dilakukan untuk mendeskripsikan aktivitas burung, habitat dan prilaku burung yang dijumpai. Sedangkan analisis kuantitatif dilakukan untuk memperoleh data kerapatan, indeks keanekaragaman jenis, indeks kekayaan, indeks kemerataan, dan kemelimpahan relatif jenis burung. Rumus-rumus yang digunakan dalam pengolahan data, antara lain:

1. Lebar jalur rata-rata

$$
\text { Lebar jalur rata-rata }=\frac{\left(I_{1} Y_{1}+I_{2} Y_{2}+I_{3} Y_{3}+I_{n} Y_{n}\right)}{Z}
$$

Keterangan :

$\mathrm{I}=$ Jumlah individu ke $\mathrm{n}$

$Y=$ Jarak individu ken

$Z=$ Jumlah total individu

2. Luas sampel transek

$$
\text { Luas sampel transek }=L \times P \text { : }
$$

Keterangan :

$\mathrm{L}=$ lebar jalur rata-rata

$P=$ panjang jalur

3. Kerapatan

$$
\text { Kerapatan }=\frac{\text { Jumlah individu tiap jenis }}{\text { luas sampel transek }}
$$




\section{Kelimpahan relatif (KR)}

Untuk mengetahui kelimpahan relatif pada lokasi pengambilan data jenis burung digunakan rumus sebagai berikut :

$$
\mathrm{KR}=\frac{\text { Kelimpahan suatu jenis }}{\text { Kelimpahan seluruh jenis }} \times 100 \%
$$

5. Indeks keanekaragaman jenis $\left(\mathrm{H}^{\prime}\right)$

Keanekaragaman jenis suatu individu dapat ditentukan dengan menggunakan indeks keanekaragaman Shannon-Wiener:

$$
H^{\prime}=\sum\left\{\left(n_{i} / n\right) \ln \left(n_{i} / n\right)\right\}
$$

Keterangan:

$\mathrm{H}^{\prime}=$ Indeks keanekaragaman Shannon-Wiener

$\mathrm{ni}=$ Jumlah individu setiap jenis

$\mathrm{n}=$ Jumlah individu seluruh jenis

Untuk menentukan keanekaragaman jenis burung, maka digunakan klasifikasi nilai indeks keanekaragaman Shannon-Wiener pada Tabel 1.

Table 1. Classification of Diversity Index Values of ShannonWiener

\begin{tabular}{cl}
\hline Nilai Indeks & \multicolumn{1}{c}{ Kategori } \\
\hline$>3$ & $\begin{array}{l}\text { Keanekaragaman tinggi, penyebaran jumlah } \\
\text { individu tiap jenis tinggi dan kestabilan } \\
\text { komunitas tinggi }\end{array}$ \\
$1-3$ & $\begin{array}{l}\text { Keanekaragaman sedang, penyebaran jumlah } \\
\text { individu tiap jenis sedang dan kestabilan } \\
\text { komunitas sedang } \\
\text { Keanekaragaman rendah, penyebaran jumlah } \\
\text { individu tiap jenis rendah dan kestabilan } \\
\text { komunitas rendah }\end{array}$ \\
\hline
\end{tabular}

6. Indeks kekayaan jenis $(R)$

Indeks kekayaan jenis burung dapat diketahui dengan rumus sebagai berikut:

Keterangan:

$$
R=S / \sqrt{n}
$$

$\mathrm{R}=$ Indeks kekayaan

$S=$ Jumlah jenis yang ditemukan

$\mathrm{N}=$ Jumlah total individu

Untuk menentukan kekayaan jenis burung, maka digunakan klasifikasi yang sama dengan nilai indeks keanekaragaman Shannon-Wiener.

\section{Indeks Kemerataan Jenis $(E)$}

Untuk mengetahui derajat kemerataan jenis pada lokasi pengambilan data jenis burung digunakan rumus sebagai berikut:

$$
E=\frac{H^{\prime}}{\operatorname{Ln} S}
$$

Keterangan:

$\mathrm{E}=$ Indeks kemerataan jenis

$H^{\prime}=$ Indeks keanekaragaman Shannon-Wiener

$S=$ Jumlah jenis yang ditemukan

Apabila nilai $\mathrm{E}$ mendekati 1 (satu) maka dikatakan merata, sedangkan jika nilai $\mathrm{E}$ mendekati 0 (nol) maka dikatakan tidak merata.

\section{HASIL}

\section{Jenis Burung}

Keanekaragaman jenis burung yang terdapat di Taman Nasional Bantimurung Bulusaraung khususnya di lokasi penelitian yaitu Leang-Leang, Pattunuang, dan Karaenta memiliki jenis burung dan kelimpahan yang berbeda. Jumlah keseluruhan jenis burung yang dijumpai pada jalur pengamatan diperlihatkan pada Tabel 2.

BerdasarkanTabel 2, diketahui bahwa ada 47 jenis burung yang ditemukan di lokasi penelitian. Jumlah jenis burung yang dijumpai pada jalur Leang-Leang sebanyak 29 jenis dengan 112 individu. Pada jalur Pattunuang dijumpai sebanyak 25 jenis dengan 69 jumlah individu. Sedangkan pada jalur Karaenta dijumpai sebanyak 13 jenis dengan 32 jumlah individu. Keseluruhan jenis burung tersebut ada yang dijumpai hanya pada satu jalur pengamatan atau tempat tertentu, ada yang dijumpai didua jalur pengamatan dan beberapa jenis yang dijumpai disetiap jalur pengamatan. Terdapat tiga jenis burung yang dijumpai pada setiap jalur pengamatan yaitu Bubut Sulawesi (Centropuscelebensis), Srigunting (Dicrurushottentottusleucops), dan Pelanduk Sulawesi (Trichastoma celebense).

Dari 47 jenis burung yang dijumpai di Taman Nasional Bantimurung Bulusaraung, 23 jenis atau 48,9\% diantaranya termasuk jenis burung yang endemik dipulau Sulawesi. Bebera pajenis burung endemik tersebut memiliki keunikan tersendiri, seperti Julang Sulawesi (Rhyticeroscassidix) yang berukuran besar $(104 \mathrm{~cm})$, memiliki kenop besar seperti tanduk pada paruh, dan suara yang sangat keras. Selain itu juga terdapat burung Kacamata Makassar (Zosteropsanomalus) burung kecil yang memiliki ukuran $12 \mathrm{~cm}$, penyebarannya hanya terbatas di Sulawesi Selatan yang sering menghuni perbukitan bersemak dan hutan sekunder serta tepi hutan, yang membedakannya dengan burung kacamata lainnya adalah memiliki lingkaran mata hitam, tenggorokan kuning, perutputih, dan penutup ekor bawah berwarna putih (Coates dan Bishop,2000).

Jenis burung yang paling banyak dijumpai pada jalur Leang-Leang adalah Cucak Kutilang (Pycnonotus aurigaster) sebanyak 21 ekor, Pada jalur Pattunuang yaitu Pergam Putih (Duculaluctuosa) sebanyak 18 ekor, dan pada jalur Karaenta yaitu Kangkareng Sulawesi (Penelopidesexarhatus) sebanyak 8 ekor. 
Table 2. The total number of bird species found on the data of observation tracks in the Bantimurung Bulusaraung National Park

\begin{tabular}{|c|c|c|c|c|c|}
\hline No & Nama Umum & Nama IImiah & Leang-leang & Pattunuang & Karaenta \\
\hline 1 & Bubutsulawesi & Centropuscelebensis & 5 & 2 & 1 \\
\hline 2 & Srigunting & Dicrurus hottentottusleucops & 4 & 3 & 4 \\
\hline 3 & PelandukSulawesi & Trichastomacelebense & 2 & 2 & 2 \\
\hline 4 & JulangSulawesi & Rhyticeroscassidix & 4 & 4 & - \\
\hline 5 & Gemakloreng & Turnixsuscitator & 4 & 2 & - \\
\hline 6 & Cabaipanggulkuning & Dicaeumaureolimbatum & 2 & 6 & - \\
\hline 7 & Elang ular sulawesi & Spilornisrufipectus & 2 & 2 & - \\
\hline 8 & Kacamata Makassar & Zosteropsanomalus & 2 & 2 & - \\
\hline 9 & Raja udangerasia & Alcedo atthis & 2 & 1 & - \\
\hline 10 & serinditsulawesi & Loriculusstigmatus & 2 & 1 & - \\
\hline 11 & Burung Madu Sriganti & Nectarinia jugularis & 1 & 2 & - \\
\hline 12 & Kangkareng Sulawesi & Penelopidesexarhatus & - & 7 & 8 \\
\hline 13 & Pelatukkelabu sulawesi & Mulleripicusfulvus & - & 2 & 3 \\
\hline 14 & Blibongpendeta & streptocittaalbicollis & - & 2 & 2 \\
\hline 15 & Ayam hutan & Gallusgallus & - & 1 & 1 \\
\hline 16 & Cekakakhutantunggir hijau & Actenoidesmonachus & - & 1 & 1 \\
\hline 17 & Kadalansulawesi & Phaenicophaeuscalyorhynchus & - & 1 & 6 \\
\hline 18 & Cucakkutilang & Pycnonotusaurigaster & 21 & - & - \\
\hline 19 & Cekakaksungai & Holcyonchloris & 7 & - & - \\
\hline 20 & Burung madu hitam & Nectarinia aspasia & 6 & - & - \\
\hline 21 & Kepudangkudukhitam & Orioluschinensiscelebensis & 6 & - & - \\
\hline 22 & SikatanMatari & Culicicapahelianthea & 1 & - & - \\
\hline 23 & Kepudang Sungu sulawesi & Coracinamorio & 2 & - & - \\
\hline 24 & Layang-layang batu & Hirundo tahitica & 2 & - & - \\
\hline 25 & Gagakhutan & Corvusenca & 2 & - & - \\
\hline 26 & Elang paria & Milvusmigrans & 12 & - & - \\
\hline 27 & Kekep Babi & Artamusleucorhynchus & 2 & - & - \\
\hline 28 & Kareo Padi & Amaurornisphoenicurus & 2 & - & - \\
\hline 29 & Opior Sulawesi & Lophozosteropssquamiceps & 2 & - & - \\
\hline 30 & BandolTaruk & Lonchura molucca & 2 & - & - \\
\hline 31 & $\begin{array}{l}\text { Kepudang Sungu Tunggir } \\
\text { Putih }\end{array}$ & Coracinaleucopygia & 2 & - & - \\
\hline 32 & Burung madu kelapa & Anthreptesmalacensis & 6 & - & - \\
\hline 33 & Bubutalang-alang & Centropusbengalensis & 2 & - & - \\
\hline 34 & Caladisulawesi & Dendrocopostemminckii & 4 & - & - \\
\hline 35 & Cekakakmerah & Halcyoncoromanda & 1 & - & - \\
\hline 36 & Gagaksulawesi & Corvustypicus & - & 2 & - \\
\hline 37 & Raja perling sulawesi & Basilorniscelebensis & - & 2 & - \\
\hline 38 & Udang merah sulawesi & Ceyxfallax & - & 1 & - \\
\hline 39 & Pergamhijau & Duculaaenea & - & 2 & - \\
\hline 40 & Merpati hitamsulawesi & Turacoenamanadensis* & - & 1 & - \\
\hline 41 & Paok mopo & Pitta erythrogaster ${ }^{+}$ & - & 1 & - \\
\hline 42 & Pergam putih & Duculaluctuosa* & - & 18 & - \\
\hline 43 & Kokokanlaut & Butorides striatus & - & 1 & - \\
\hline 44 & Cabai Panggul kelabu & Dicaeumcelebicum & - & - & 1 \\
\hline 45 & Perkici kuning-hijau & flavoviridis**+ & - & - & 1 \\
\hline 46 & Tekukur biasa & Streptopeliachinensis & - & - & 1 \\
\hline 47 & Celepuk sulawesi & Otus manadensis*+ & - & - & 1 \\
\hline \multicolumn{3}{|c|}{ Total } & 112 & 69 & 32 \\
\hline
\end{tabular}


Tabel 3. Ecologicalindex on observation tracks in the Bantimurung Bulusaraung National Park

\begin{tabular}{clccc}
\hline No & \multicolumn{1}{c}{ Jalur Pengamatan } & Indeks kekayaan & Indeks kemerataan & Indeks keanekaragaman \\
\hline 1 & Leang -Leang & 2,63 & 0,90 & 3,02 \\
2 & Pattunuang & 3,01 & 0,86 & 2,78 \\
3 & Karaenta & 2,30 & 0,88 & 2,25 \\
\hline
\end{tabular}

Table 4. The calculation results of relative abundance on observationtracks in the Bantimurung Bulusaraung National Park

\begin{tabular}{llcccc}
\hline No & Jalur Pengamatan & Luas & Jumlah indv. & $\mathrm{K}$ (Ind/Ha) & KR\% \\
\hline 1 & Leang -Leang & 3,82 & 112 & 29,32 & 57,17 \\
2 & Pattunuang & 5,68 & 69 & 12,15 & 23,69 \\
3 & Karaenta & 3,26 & 32 & 9,82 & 19,14 \\
\hline & & & 213 & 51.28 & 100 \\
\hline
\end{tabular}

\section{Indeks Ekologi}

Hasil analisis nilai indeks ekologi pada ketiga jalur pengamatan diperlihatakan pada Tabel 3. Berdasarkan data pada Tabe 13. Diketahui nilai indeks keanekaragaman jenis burung $\left(H^{\prime}\right)$, indeks kekayaan jenis $(R)$, dan indeks kemerataan jenis $(E)$ pada setiap jalur pengamatan. Nilai indeks kekayaan jenis tertinggi terdapat pada jalur Pattunuang yaitu sebesar 3,01 sedangkan nilai indeks kekayaan terendah berada pada jalur Karaenta yaitu 2,30. Nilai indeks kemerataan tertinggi terdapat pada jalur Leang-Leang yaitu sebesar 0,90 sedangkan nilai kemerataan terendah berada pada jalur Pattunuang yaitu 0,86 . Indeks keanekaragaman tertinggi terdapat pada jalur Leang-Leang yaitu 3,02 sedangkan indeks keanekaragaman terendah terdapat pada jalur Karaenta yaitu 2,25. Berdasarkan klasifikasi Shannon-wiener (Irwanto, 2008), keanekaragaman jenis burung pada jalur Leang-Leang tergolong tinggi yang berarti penyebaran jumlah individu tiap jenis tinggi dan kestabilan komunitas tinggi, sedangkan keanekaragaman jenis pada jalur Pattunuang dan Karaenta tergolong sedang yang berarti penyebaran jumlah individu tiap jenis sedang dan kestabilan komunitas sedang.

Tipe vegetasi yang ada pada jalur Leang-Leang dominan memiliki tutupan lahan terbuka yang berupa hutan karst, semak, tegakan jati, dan sawah. Pada jalur Pattunuang tutupan vegetasi relatif berupa hutan alam dan semak. Sedangkan pada jalur Karaenta tutupan vegetasi berupa tegakan kembang kecrutan dan hutan alam yang penutupan tajuknya lebih rapat.

\section{Kelimpahan Jenis Burung}

Diantara ketiga jalur pengamatan, jalur LeangLeang memiliki jumlah individu burung terbanyak yaitu 112 individu sedangkan jalur karaenta memiliki jumlah individu terkecil yaitu 32 individu. Hasil perhitungan menunjukkan bahwa, luas plot sampel yang terdapat di jalur Leang-Leang yaitu seluas $3,82 \mathrm{Ha}$, pada jalur Pattunuang seluas $5,68 \mathrm{Ha}$ dan jalur Karaenta seluas $3,26 \mathrm{Ha}$. Perbedaan jumlah individu dan luas plot sampel menyebabkan adanya perbedaan kelimpahan populasi seluruh spesies pada setiap Jalur pengamatan. Hasil perhitungan kelimpahan populasi burung disetiap jalur pengamatan diperlihatkan pada Tabel 4 .

Berdasarkan Tabel 4 diketahui bahwa, kelimpahan populasi tertinggi terdapat pada jalur LeangLeang yaitu sebesar 29 individu/Ha sedangkan kelimpahan populasi terendah terdapat pada jalur Karaenta yaitu sebesar 9 individu/Ha. Nilai kelimpahan berbanding lurus dengan nilai kelimpahan relatif artinya semakin tinggi nilai kelimpahan maka semakin tinggi pula nilai kelimpahan relatifnya dan sebaliknya semakin rendah nilai kelimpahan maka semakin rendah pula nilai kelimpahan relatifnya.

\section{Jalur wisata Bird Watching}

Berdasarkan hasil analisa keanekaragaman dan kelimpahan jenis burung pada ketiga jalur pengamatan, dapat disimpulkan bahwa ketiga jalur pengamatan tersebut berpotensi untuk dijadikan sebagai jalur wisata Bird watching. Masing-masing jalur pengamatan memiliki komposisi jenis burung dan karakteristik jalur yang berbeda. Pada jalur pengamatan yang terdapat di LeangLeang memiliki kondisi medan yang datar sehingga tidak sulit untuk dilewati. Jalur pengamatan dimulai dari Taman Prasejarah Leang-Leang dan berakhir di Dusun Panaikang dengan melewati tipe penutupan lahan berupa hutan karst, sawah, semak, dan hutan jati. Sebagian besar jalur berada di luar kawasan Taman Nasional Bantimurung Bulusaraung, disebabkan kondisi bentangan alam yang tidak memungkinkan untuk membuat jalur pengamatan yang baik di dalam kawasan, yaitu adanya deretan tebing karst yang tidak bisa dilewati untuk bisa masuk kedalam kawasan. Dengan mempertimbangkan beberapa hal, maka dipilih jalur yang melewati batas antara sawah dan tebing karst karena terdapat banyak jenis burung yang dapat dijumpai serta kondisi jalur yang aman dan nyaman dilewati.

Jalur pengamatan di Pattunuang dimulai dari penangkaran Tarsius (Tarsius spectrum) dan berakhir di daerah wisata Biseang Labboro. Secara keseluruhan, 
medan yang dilewati berupa jalur yang relatif datar dan sedikit pendakian yang agak terja diawal jalur, namun bukan hal yang sulit untuk dilewati karena terdapat beberapa anak tangga yang dapat mempermudah perjalanan dalam pengamatan. Terdapat shelter yang dapat digunakan untuk beristrahat yang berjarak $200 \mathrm{~m}$ dari penangkaran Tarsius (Tarsius spectrum).

Jalur pengamatan di Karaenta sepanjang 2.000 m, dengan kondisi jalur yang relatif datar sampai landai melewati hutan primer yang penutupannya rapat. Jalur pengamatan dimulaidari pos kehutanan yang berupa shelter berada dipinggir jalan poros Camba- Maros dan berakhir di Dusun Kappang.

\section{PEMBAHASAN}

Keanekaragaman jenis burung yang ada di kawasan Taman Nasional Bantimurung Bulu saraung memiliki potensi wisata yang dapat dijadikan sebagai objek kegiatan wisata bird watching. Kawasan tersebut kaya akan sumberdaya alam yang mendukung sumber kehidupan berbagai jenis burung, salah satunya yaitu sumber makanan yang banyak. Sebagian besar burungburung yang di temukan makanannya berupa seranggaserangga kecil dan buah-buahan. Menurut Tews et al (2004) dalam Dewi dkk (2007), beragamnya jenis vegetasi yang terdapat pada suatu habitat mendukung ketersediaan pakan bagi burung, sehingga dengan beragamnya jenis vegetasi maka burung akan mendapatkan pilihan yang lebih banyak untuk memilih jenis pakan.

Faktor tingginya keanekaragaman pada jalur LeangLeang dibandingkan dengan jalur pengamatan yang lainnya disebabkan oleh banyaknya sumber pakan berupa serangga-serangga kecil, buah-buahan dan tingginya keanekaragaman habitat. Menurut Tortosa (2000), keanekaragaman jenis burung dipengaruhi oleh keanekaragaman tipe habitat. Semakin beranekaragam struktur habitat (keanekaragaman jenis tumbuhan dan struktur vegetasi) maka akan semakin besar keanekaragaman jenis burung. Struktur vegetasi dan ketersediaan pakan pada habitat merupakan faktor utama yang mempengaruhi keanekaragaman jenis di suatu habitat. Selanjutnya menurut Krebs dan Davies (1978), ketidak hadiran suatu jenis burung disuatu tempat disebabkan oleh beberapa faktor diantaranya ketidakcocokan habitat, perilaku (seleksi habitat), kehadiran jenis hewan lain (predator, pesaing, dan parasit), dan faktor kimia-fisika lingkungan yang berada di luar kisaran toleransi jenis burung yang bersangkutan.

Terdapat beberapa aktivitas yang dilakukan oleh burung yang ditemukan selama penelitian antara lain makan, vokal atau bersuara, dan pindah atau bergerak. Menurut Van Tyne dan Beger (1976) dalam Fachrul (2008) aktivitas tersebut merupakan aktivitas umum yang dilakukan oleh jenis burung. Aktivitas makan diperlukan guna mendapatkan energi untuk melakukan aktivitas- aktivitas harian seperti terbang dan berinteraksi dengan yang lainnya. Pakan yang dibutuhkan oleh burung dapat terlihat dari habitat dimana burung itu berada. Aktivitas vokal atau bersuara merupakan suatu bentuk interaksi atau hubungan dengan yang lainnya, aktivitas tersebut dapat berupa nyanyian, panggilan, melakukan penyerangan, mempertahankan daerah teritori saat di sarang, ataupun berupa tanda adanya ancaman dari predator. Kemudian aktivitas pindah atau bergerak adalah suatu strategi dari individu maupun populasi untuk menyesuaikan dan memanfaatkan keadaan lingkungannya agar dapat hidup dan berkembangbiak secara normal. Aktivitas berpindah dapat terjadi setiap waktu seperti saat mencari makan atau menjaga daerah teritori.

Dari hasil penelitian yang diperoleh, terdapat 16 atau $34 \%$ jenis burung yang dilindungi baik pemerintah lokal maupun Internasional. Hal tersebut menandakan bahwa kawasan Taman Nasional Bantimurung Bulusaraung mampu mendukung kehidupan baik jenis yang endemik secara umum maupun jenis-jenis yang terancam punah. Berdasarkan PP No 7 Tahun 1999 jenis burung yang dilindungi antara lain Burung Madu Sriganti (cinnyrisjugularis), Burung Madu Hitam (leptocomasericea), Burung Madu Kelapa (Anthreptesmalacensis), Paok Mopo (Pittaerythrogaster), Cekakak Merah (Halcyon coromanda), Raja Udang Erasia (Alcedoatthis), dan Cekakak Sungai (Holcyonchloris). Berdasarkan Conventionon International Trade of Endangered Species of Wild Fauna and Flora (CITES), jenis burung yang digolongkan dalam Appendix II yaitu Perkici Kuning Hijau (Trichoglossus flavoviridis), dan Serindit Sulawesi (Loriculusstigmatus). Selain dilindungi oleh pemerintah lokal juga digolongkan dalam Appendix II oleh CITES adalah Julang Sulawesi (Rhyticeroscassidix), Kangkareng Sulawesi (Penelopides exarhatus), Celepuk Sulawesi (Otus manadensis), Elang Ular Sulawesi (Spilornis rufipectus), dan Elang Paria (Milvus migrans). Sedangkan jenis yang dilindungi oleh pemerintah lokal dan dalam Redlist International Union for Conservation of Nature (IUCN) dikategorikan Near Threatened atau mendekati terancam yaitu Cekakak Tunggir Hijau (Actenoides monachus) dan Udang Merah Sulawesi (Ceyxfallax).

Aktivitas pengamatan burung merupakan aktivitas yang membutuhkan konsentrasi tinggi dan menitikberatkan pada proses mencari burung, mengidentifikasi, dan mencatatnya. Jalur yang tidak baik akan membuat energi cepat terkuras sehingga konsentrasi pengamat burung bisa terganggu. Berdasarkan hasil penelitian, jalur pengamatan LeangLeang merupakan jalur yang terbaik dibandingkan jalur pengamatan yang lainnya karena jalur tersebut memiliki tingkat kenyamanan dan keamanan yang baik serta tipe habitat yang bervariasi memberi peluang hadirnya berbagai macam jenis burung sehingga sangat 
mendukung untuk pengembangan wisata pengamatan burung (Birdwatching).

\section{E. KESIMPULAN}

Adapun kesimpulan yang dapat diambil dari keseluruhan hasil penelitian ini adalah sebagai berikut :

1. Terdapat 47 jenis burung yang ditemukan pada ketiga jalur pengamatan dan 23 jenis diantaranya (48,9\%) termasuk jenis endemik di pulau Sulawesi

2. Keanekaragaman jenis burung pada ketiga jalur pengamatan di Taman Nasional Bantimurung Bulusaraung mempunyai nilai indeks keanekaragaman berkisar antara 2,25 - 3,02 (sedang sampai tinggi)

3. Jenis burung yang ditemukan pada ketiga jalur pengamatan memiliki potensi yang sangat besar untuk dijadikan objek wisata bird watching.

4. Jalur pengamatan Leang-Leang, Pattunuang, dan Karaenta berpotensi sebagai jalur wisatabird watching.

\section{F. DAFTAR PUSTAKA}

Achmad, A. 2011. Rahasia Ekosistem Bukit Kapur. Brilian Internasional, Surabaya.

Coates, B. J., K. D. Bishop, and D. Gardner. 2000. Panduan Lapangan Burung-Burung di Kawasan Wallace;Sulawesi, Maluku dan Nusa Tenggara. Bird life International-Indonesia Programme, Bogor, Indonesia.

Irwanto. 2008. Indeks diversitas/keanekragaman. https://irwanto.info/ files/indeks diversitas.pdf. Diakses pada 17 Maret 2018

Dewi, R.S., Y. Mulyani dan Y. Santosa. 2007. Keanekaragaman Jenis Burung di Beberapa Tipe Habitat Taman Nasional Gunung ceremai. Yayasan Penerbit IPB, Bogor.

Fachrul M. F., 2008, Metode Sampling Bioteknologi, Bumi Aksara, Jakarta.

Krebs, J. R. And Davies, N. B. 1978. Behaviouralecology: anevolutionary approach. 3rd ed. Blackwell Scientific Publications, London.

Soegianto, A. 1994. Ekologi Kuantitatif. Usaha Nasional, Surabaya

Taman Nasional Bantimurung Bulusaraung. 2012. Rencana Kerja Balai Taman Nasional Bantimurung Bulusaraung 2013. Maros.

Tortosa FS. 2000. Habitat Selection by Flocking Wintering Common Cranes (Grusgrus) at Los Pedroches Valley, Spain. Etologia 8:21-24. 